\title{
PENGKAYAAN SUMBERDAYA IKAN DENGAN FISH APARTMENT DI PERAIRAN BANGSRING, BANYUWANGI
}

\section{FISH RESOURCES ENRICHMENT WITH FISH APARTMENT IN THE WATERS BANGSRING, BANYUWANGI}

\author{
Muhammad Wildy Kamaali ${ }^{1}$, Mulyono S. Baskoro ${ }^{2}$, Sugeng Hari Wisudo ${ }^{2}$ \\ ${ }^{1}$ Program Studi Teknologi Perikanan Laut, Sekolah Pascasarjana \\ ${ }^{2}$ Departemen Pemanfaatan Sumberdaya Perikanan, \\ Fakultas Perikanan dan Ilmu Kelautan, Institut Pertanian Bogor \\ Korepondensi: daniel_rezki@yahoo.com
}

\begin{abstract}
The use of fishing gear which is not enviromentally can involve aquatic ecosystems damage where is, mainly for fish habitats damage such as coral reefs. Damaged coral reefs resulting in captures reduced, fish captures decrease, and the loss of some fish species on that water region, especially reef fishes. This fish apartment development and determine the direct impact to the Bangsring fisherman. Determining teh abudance and diversity of fish species as an indicator in the Bangsring waters. Analyze the success level of fish apartment in enrichment of fish stoks and improve fish babitats in Bangsring, Banyuwangi. Fish apartment cultivation on Bangsring waters could restore the enrichment of fish resources, seen from the accretion of fish species, the increasing of fish captured up to $100 \%$, capture distance that near, and efficient at the time of capturing. Fish apartment could restore aquatic ecosystems damaged, especially on Bangsring waters.
\end{abstract}

Keyword: Bangsring water, Banyuwangi, fish apartment, restocking

\begin{abstract}
ABSTRAK
Penggunaan alat tangkap yang tidak ramah lingkungan dapat mengakibatkan rusaknya ekosistem perairan, terutama kerusakan habitat ikan seperti terumbu karang. Terumbu karang yang rusak mengakibatkan hasil tangkapan berkurang, ikan hasil tangkapan semakin mengecil, dan hilangnya beberapa jenis ikan di perairan tersebut, khususnya ikan karang. Penelitian ini diharapkan mampu memberikan gambaran tentang perkembangan fish apartment dan mengetahui dampak langsung terhadap nelayan di daerah Bangsring, Banyuwangi. Menentukan kelimpahan dan keanekaragaman jenis ikan sebagai indikator diperairan di Bangsring. Menganalisis tingkat keberhasilan fish apartment dalam pengkayaan stok ikan dan memperbaiki habitat ikan pada perairan Bangsring. Penanaman fish apartment pada perairan Bangsring, Banyuwangi dapat mengembalikan kekayaan sumber daya ikan, dilihat dari keberhasilan pertambahan jenis ikan, meningkatnya hasil tangkapan hingga 100\%, dan jarak penangkapan yang dekat dan efisien dalam waktu penangkapan. Fish apartment dapat mengembalikan ekosistem perairan yang rusak, khususnya di perairan Bangsring, Banyuwangi, Jawa Timur.
\end{abstract}

Kata kunci: Banyuwangi, fish apartment, pengkayaan sumberdaya, perairan Bangsring 


\section{PENDAHULUAN}

\section{Latar belakang}

Penangkapan ikan hias di perairan pantai Bangsring, Banyuwangi telah dilakukan sejak 1970. Perkembangan tiap tahun semakin banyak nelayan yang memanfaatkan daerah perairan pantai untuk menangkap ikan hias di perairan Bangsring. Persaingan untuk mendapatkan ikan hasil tangkapan semakin tinggi, sehingga pada tahun 1980 banyak nelayan yang melakukan penangkapan ikan dengan potas dan bahan peledak. Penangkapan dengan potas oleh nelayan dikarenakan mudah dan murah dalam menggunakannya, akan tetapi penggunaan bahan tersebut dapat mengancam ekosistem. Kerusakan terumbu karang lebih disebabkan oleh faktor yang bersumber dari aktivitas manusia seperti penangkapan ikan menggunakan bahan peledak atau racun seperti potas dan sianida (Mulatsih 2004).

Penggunaan alat tangkap yang tidak ramah lingkungan dapat mengakibatkan rusaknya ekosistem perairan, terutama kerusakan habitat ikan seperti terumbu karang. Terumbu karang yang rusak mengakibatkan hasil tangkapan berkurang, ikan hasil tangkapan semakin mengecil, dan hilangnya beberapa jenis ikan di perairan tersebut, khususnya ikan karang. Menurut Connel (1987), diantara komponen biotik ikan merupakan salah satu organisme akuatik yang rentan terhadap perubahan lingkungan, terutama yang diakibatkan oleh aktivitas manusia baik secara langsung maupun tidak langsung.

Kondisi perairan yang rusak dan tercemar ikan akan berpindah tempat dan mencari habitat baru. Menurut Anwar et al. (1984), komposisi dan distribusi ikan sangat dipengaruhi oleh perubahan parameter seperti fisik, kimia, dan biologi perairan. Salah satu faktor yang mempengaruhi sulitnya habitat ikan kembali adalah rusaknya karang di perairan. Kerusakan karang menjadikan ikan sulit untuk berkembang biak. Secara ekologis, tipologi habitat tersebut sangat penting bagi keberlanjutan ekosistem perairan, karena memiliki fungsi sebagai daerah pemijahan (spawning grouna), sebagai area pengasuhan serta pertumbuhan (nursery grouna), dan mencari makan (feeding grouna) (Budhiman et al. 2013). Kerusakan perairan harus di cegah dan di perbaiki agar sumberdaya ikan tidak habis, salah satunya dengan membuat fish apartment yang diciptakan oleh Balai Besar Pengembangan Penangkapan Ikan (BBPPI) Semarang. Terciptanya fish apartment ditujukan sebagai pengganti terumbu karang dan menjaga keberlanjutan pemanfaatan sumberdaya ikan.

Fish apartment pada saat ini sudah dikembangkan di berbagai daerah Indonesia, akan tetapi masih belum diketahui secara pasti perkembangan fish apartment akan keberhasilan untuk mengembalikan ekosistem perairan. Penanaman fish apartment ini salahsatunya pada daerah Bangsring Banyuwangi. Pemilihan lokasi penelitian Bangsring Banyuwangi tersebut dikarenakan adanya sejarah kerusakan perairan dan berkurangnya hasil tangkapan yang dikarenakan alat tangkap yang tidak ramah lingkungan. Kerusakan perairan tersebut berdampak pada pendapatan masyarakat nelayan, sehingga dengan meilih lokasi bangsring sebagai lokasi diharapkan dapat mengetahui dampak penanaman fish apartment terhadap perairan khususnya pada perairan Bangsring, Banyuwangi.

Kerusakan karang di perairang Bangsring, Banyuwangi pun tidak dapat dihindarkan lagi, hingga pada tahun 1990 pendapatan nelayan semakin berkurang dan sulit untuk mendapatkan ikan. Sulitnya mendapatkan ikan menjadikan nelayan melakukan penangkapan mencari daerah penangkapan ikan baru dan dibantu dengan alat kompresor. Pada tahun 2008 kelompok nelayan mencari solusi pengembalian ekosistem perairan Bangsring. Banyak upaya yang dilakukan nelayan untuk mengembalikan ekosistem perairan di Bangsring salah satunya penanaman fish apartment.

Penelitian fish apartment ini memiliki tujuan menentukan kelimpahan jenis ikan sebagai indikator perairan diperairan Banyuwangi. Menganalisis tingkat keberhasilan fish apartment dalam memperbaiki habitat ikan dan diharapkan mampu memberikan gambaran tentang perkembangan fish apartment dan mengetahui dampak langsung terhadap nelayan di daerah Bangsring, Banyuwangi.

\section{METODE PENELITIAN}

Penanaman fish apartment untuk pemulihan perairan di daerah Bangsring, Banyuwangi, dimulai pada tahun 2011 dimana dilakukan penanaman 50 unit yang terletak tidak jauh dari pantai. Penanaman tersebut dilakukan karena ekosistem perairan pantai mengalami kerusakan yang parah dan konstruksi perairan yang layak untuk penanaman fish apartment. Tahun 2012 penanaman fish apartment ditambah 95 unit dan 2013 penanaman 95 unit, total penanaman fish apartment di daerah Bangsring mencapai 240 unit dengan luas lahan \pm 2 hektar. Penanaman fish apartment pada daerah Bangsring diletakan pada perairan pantai dan dijadikan daerah konservasi, dimana wilayah tersebut dilindungi dan dijaga oleh masyarakat dan instansi terkait.

Menurut

Martasuganda

(2008) fish apartment tergolong ke dalam jenis rumpon dasar, hal tersebut dikarenakan sifat rumpon dasar yang dapat berfungsi seperti pengganti terumbu karang. Dilihat dari fungsi dan manfaatnya fish apartment merupakan pengembangan dari rumpon dasar, sehingga fish apartment dapat diidentikkan dengan rumpon dasar. 
Perbedaan fish apartment dengan rumpon adalah bahan utama yang digunakannya. Fish apartment menggunakan bahan utama plastik (Bambang et al. 2011). Rumpon atau yang biasa disebut dengan Fish aggregation Device (FAD) adalah potongan kayu, atau daun-daun yang direndam di dalam air yang menarik ikan untuk berkumpul (Mallawa 2004). Perbedaan fish apartment dan rumpon dasar dapat dilihat pada Gambar 1 .

Penelitian ini dilakukan di perairan pantai Bangsring, Banyuwangi, Jawa Timur. Penelitian dilakukan pada bulan FebruariMaret 2015. Pengambilan data dilakukan dengan metode purposive sampling yaitu melakukan wawancara langsung dengan para pelaku yang ada di setiap lokasi penangkapan ikan. Wawancara dilakukan terhadap nelayan penangkap ikan di perairan Bangsring, Banyuwangi.

Penelitian ini merupakan penelitian menganalisis fish apartment untuk perbaikan lingkungan, yaitu dengan menggambarkan sebuah mekanisme sebuah proses atau hubungan antara terumbu karang yang rusak dengan fish apartment. Proses mekanisme tersebut dapat diubah menjadi informasi dasar akan hubungan fish apartment dan lingkungan, kemudian dapat mengklasifikasikan fish apartment apakah memiliki pengaruh untuk mengembalikan habitat ikan di suatu perairan. Data yang akan diperoleh berupa:

- Pencatatan jenis dan individu ikan yang tertangkap di sekitar fish apartment, komposisi jenis (Greenberg 1989):

$$
K J=\frac{N I}{I} X 100 \%
$$

Keterangan :

$\mathrm{KJ}=$ Komposisi jenis

ni $=$ Jumlah individual setiap jenis

$\mathrm{N}=$ Jumlah individu seluruh jenis

- Pengumpulan data dengan wawancara dan atau kuesioner.

Wawancara dilakukan terhadap nelayan Bangsring, Banyuwangi dengan mengumpulkan data jenis alat tangkap, rata-rata hasil tangkapan harian pernelayan, jarak penangkapan dan waktu penangkapan. Pengumpulan data alat tangkap yang digunakan oleh nelayan yaitu untuk menentukan dukungan nelayan terhadap penangkapan yang ramah dan mendukung perbaikan lingkungan, dengan menggunakan alat tangkap yang ramah lingkungan tentu dapat mempengaruhi hasil dari tangkapan ikan dan faktor pendukung lainnya terhadap fish apartment. Data ratarata hasil tangkapan dapat mengetahui jumlah hasil tanggkapan sesudah dan sebelum adanya fish apartment yang kemudian dapat dibandingkan untuk mengetahui pengaruh dan perkembangan fish apartment. Jarak penangkapan sangat berpengaruh terhadap waktu penangkapan, dimana semakin jauh lokasi penangkapan ikan akan semakin membutuhkan waktu dalam penangkapan ikan. olehkarena itu dilakukan penilaian efisiensi waktu nelayan ketika sebelum dan sesudah adanya fish apartment. Penentuan jarak penangkapan ikan yaitu dekat $=0-1 \mathrm{mil}$, sedang $=1-2$ mil, dan jauh $=2-3$ mil.

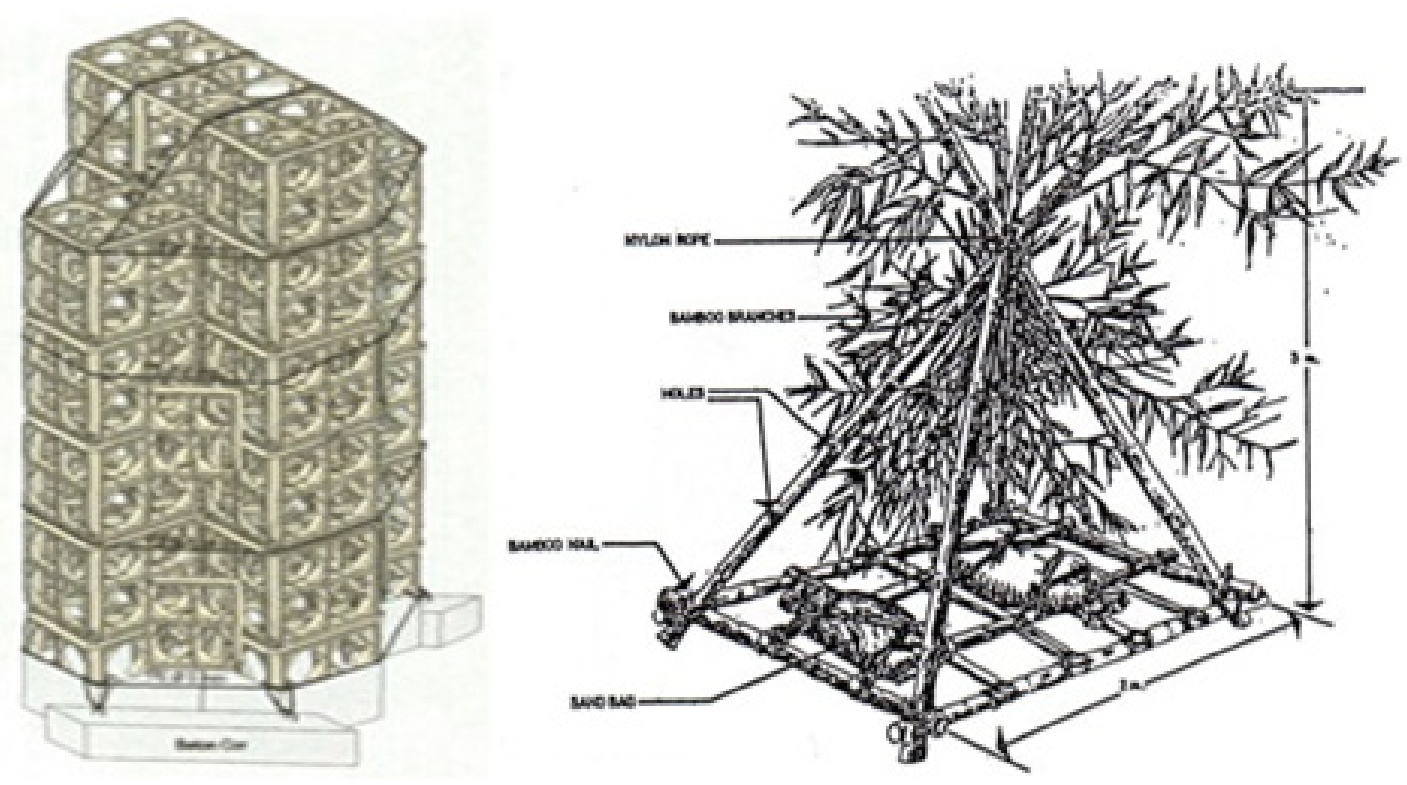

Gambar 1. Fish apartment dan rumpon dasar 


\section{HASIL DAN PEMBAHASAN}

Dengan adanya penanaman fish apartment dapat dilihat grafik hasil tangkapan tahun 2012-2015 pada Gambar 2 . Hasil tangkapan ikan hias pada tahun 2012-2013 mengalami penurunan. Hal tersebut dikarenakan ikan hasil tangkapan ikan pada tahun 2012 tidak seluruhnya dari hasil tangkapan perairan Bangsring, Banyuwangi. Sedikitnya ikan hasil tangkapan pada daerah Bangsring menjadikan nelayan mencari lokasi penangkapan ikan lebih jauh. Pencarian ikan oleh nelayan Bangsring semakin jauh, dimana penangkapan ikan dapat mencapai pulau Bali. Jarak penangkapan ikan yang semakin jauh menjadikan penangkapan ikan menjadi tidak efisien, hal tersebut dikarenakan tidak sebandingnnya biaya oprasional dan hasil tangkapan.
Menurut Mahyudin (2012), menurunnya hasil tangkapan nelayan, semakin kecilnya ukuran ikan yang tertangkap, sulit dan jauhnya mencari daerah penangkapan (fishing grouna) dan langkanya beberapa spesies ikan dikarenakan rusaknya kondisi lingkungan dan indikasi overfishing. Penurunan sumberdaya ikan di Bangsring merupakan dampak dari interaksi antara aktivitas penangkapan menggunakan alat dan bahan yang tidak ramah lingkungan seperti bom ikan dan potasium sianida. Penggunaan bahan yang tidak ramah lingkungan tentu akan berdampak pada menurunnya daya dukung perairan Bangsring Banyuwangi.

Data hasil penelitian, tangkapan ikan hias di Bangsring, Banyuwangi dari tahun 2013-2015 mengalami peningkatan. Hasil tangkapan pada tahun 2013-2015 mengalami peningkatan, dengan nilai

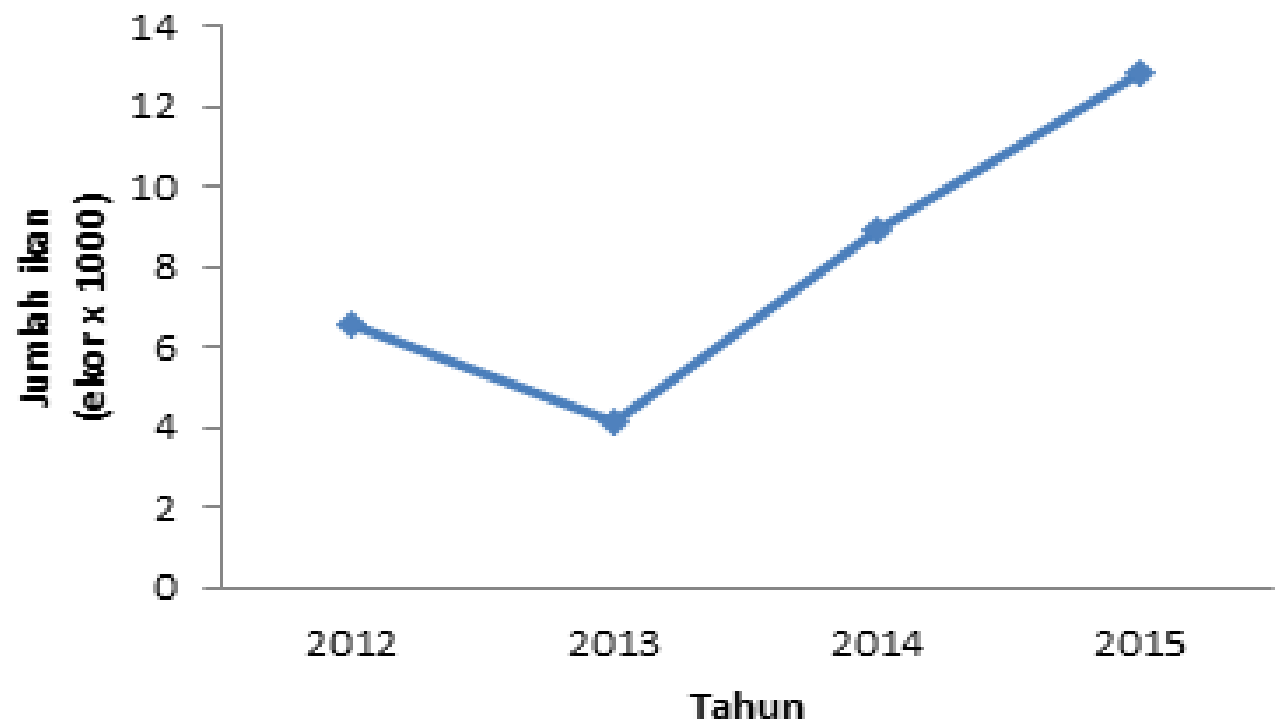

Gambar 2. Grafik data penelitian perkembangan hasil tangkapan ikan hias di Bangsring, Banyuwangi tahun 2012-2015

4.130 ekor pada tahun 2013, 8.949 ekor tahun 2014, dan 12.844 ekor pada tahun 2015 (Tabel 1). Nilai persentase rata-rata kenaikan hasil tangkapan tahun 2013-2015 adalah $80 \%$ per tahun. Tahun 2013 nelayan sudah tidak terlalu jauh untuk mencari ikan, hal tersebut dikarenakan sudah mulai kembalinya beberapa jenis ikan di perairan Bangsring. Meningkatnya hasil tangkapan di Bangsring menandakan adanya pengaruh antara hasil tangkapan dan penanaman fish apartment. Penanaman fish apartment yang bertahap dari tahun 2011 memang tidak langsung memberikan dampak pengembalian perbaikan lingkungan suatu perairan, akan tetapi dengan dukungan wilayah konservasi perkembangan perbaikan menggunakan fish apartment dari tahun 2013-2015 mengalami perbaikan yang cukup signifikan.
Menurut Sutarto (2000), fishapartment /terumbu karang buatan memiliki fungsi yang hampir sama seperti terumbu karang, hal tersebut karena dapat menarik dan mengumpulkan ikan dan kehidupan laut lainnya dengan cara menyediakan tempat berlindung dan sumber makanan tambahan dengan substrat yang luas. Secara umum fish apartment yang dipasang secara nyata telah memberikan fungsi sebagai pengumpul ikan dengan bertambahnya bangunan dasar atau topografi. Bertambahnya daya dukung lingkungan telah memberikan kemungkinan bertambahnya biomassaikan-ikan setempat. Peningkatan jumlah hasil tangkapan tentu diiringi dengan bertambahnya jumlah jenis ikan. Bertambahnya jenis ikan menandakan kembalinya beberapa ikan yang dulu sempat hilang di perairan Bangsring, Banyuwangi. Ikan hasil tangkapan dapat dilihat pada Tabel 1, setiap jenis ikan di kelompokan 
berdasarkan famili.

Hasil pengamatan visual terumbu karang buatan dengan penyelaman didapatkan beberapa jenis ikan dominan seperti Pomacentridae, Labridae, Chaetodotidae, Serranidae, Siganidae, dan Pomacanthidae (Hutomo 1991). Ikan hasil tangkapan nelayan Bangsring memiliki variasi yang beragam. Tahun 2012 di dapatkan jenis ikan 36 famili dengan 164 jenis ikan yang tertangkap, mayoritas hasil tangkapan dari famili Labridae $33.90 \%$, Pomacentridae $26.59 \%$ dan Serranidae 6.02\%. Tahun 2013 didapatkan ikan hasil tangkapan 30 famili dengan 135 jenis ikan yang tertangkap, dengan mayoritas hasil tangkapan adalah Pomacentridae 50.27\%, Labridae $24.12 \%$ dan Gobiidae $4.62 \%$. Tahun 2014 didapatkan ikan hasil tangkapan 32 famili dengan 156 jenis ikan yang tertangkap, dengan mayoritas hasil tangkapan adalah Pomacentridae $36.67 \%$, Labridae $29.52 \%$ dan Serranidae 7.78\%. Tahun 2015 didapatkan ikan hasil tangkapan 35 famili dengan 191 jenis ikan yang tertangkap, dengan mayoritas hasil tangkapan adalah Labridae $32.86 \%$, Pomacentridae $31.57 \%$, dan Pomacanthidae 7.22\%. Grafik data jenis hasil tangkapan bias dilihat pada Gambar 3 , sedangkan contoh jenis ikan hias hasil tangkapan nelayan Bangsring Banyuwangi dapat dilihat pada Gambar 4.

Tabel 1. Data jenis ikan tangkapan di sekitar fish apartment Bangsring, Banyuwangi digolongkan per famili

\begin{tabular}{llcc}
\hline \multicolumn{4}{c}{$\mathbf{2 0 1 2}$} \\
\hline No & \multicolumn{1}{c}{ Famili } & n Ekor & $\%$ \\
\hline 1 & Labridae & 2.235 & 33.90 \\
2 & Pomancetridae & 1.753 & 26.60 \\
3 & Serranidae & 397 & 6.00 \\
4 & Acanthuridae & 365 & 5.50 \\
5 & Pseudochromidae & 328 & 5.00 \\
6 & Gobiidae & 322 & 4.90 \\
7 & Pomacanthidae & 256 & 3.90 \\
8 & Chaetodontidae & 177 & 2.70 \\
9 & Mullidae & 169 & 2.60 \\
10 & Lain-lain & 590 & 8.90 \\
& & 6.592 & 100.00 \\
\hline
\end{tabular}

\begin{tabular}{llcc}
\hline \multicolumn{4}{c}{$\mathbf{2 0 1 3}$} \\
\hline No & \multicolumn{1}{c}{ Famili } & n Ekor & \% \\
\hline 1 & Pomancetridae & 2.076 & 50.30 \\
2 & Labridae & 996 & 24.10 \\
3 & Gobiidae & 191 & 4.60 \\
4 & Acanthuridae & 95 & 2.30 \\
5 & Malacostraca & 86 & 2.10 \\
6 & Serranidae & 83 & 2.00 \\
7 & Microdesmidae & 76 & 1.80 \\
8 & Pomacanthidae & 71 & 1.70 \\
9 & Chaetodontidae & 69 & 1.70 \\
10 & Lain-lain & 386 & 9.20 \\
& & 4.129 & 100.00 \\
\hline
\end{tabular}

\begin{tabular}{llcc}
\hline \multicolumn{4}{c}{$\mathbf{2 0 1 4}$} \\
\hline No & \multicolumn{1}{c}{ Famili } & n Ekor & \% \\
\hline 1 & Pomancetridae & 3.282 & 36.70 \\
2 & Labridae & 2.642 & 29.50 \\
3 & Serranidae & 696 & 7.80 \\
4 & Pomacanthidae & 570 & 6.40 \\
5 & Pseudochromidae & 302 & 3.40 \\
6 & Acanthuridae & 281 & 3.10 \\
7 & Chaetodontidae & 196 & 2.20 \\
8 & Malacostraca & 163 & 1.80 \\
9 & Teraodontidae & 145 & 1.60 \\
10 & Lain-lain & 672 & 7.50 \\
& & 8.949 & 100.00 \\
\hline
\end{tabular}

\begin{tabular}{llcc}
\hline \multicolumn{4}{c}{$\mathbf{2 0 1 5}$} \\
\hline No & \multicolumn{1}{c}{ Famili } & n Ekor & \% \\
\hline 1 & Labridae & 4.220 & 32.90 \\
2 & Pomancetridae & 4.055 & 31.60 \\
3 & Pomacanthidae & 927 & 7.20 \\
4 & Acanthuridae & 685 & 5.30 \\
5 & Malacostraca & 566 & 4.40 \\
6 & Serranidae & 526 & 4.10 \\
7 & Gobiidae & 380 & 3.00 \\
8 & Pseudochromidae & 328 & 2.60 \\
9 & Mullidae & 259 & 2.00 \\
10 & Lain-lain & 898 & 7.00 \\
& & 12.844 & 100.00 \\
\hline
\end{tabular}



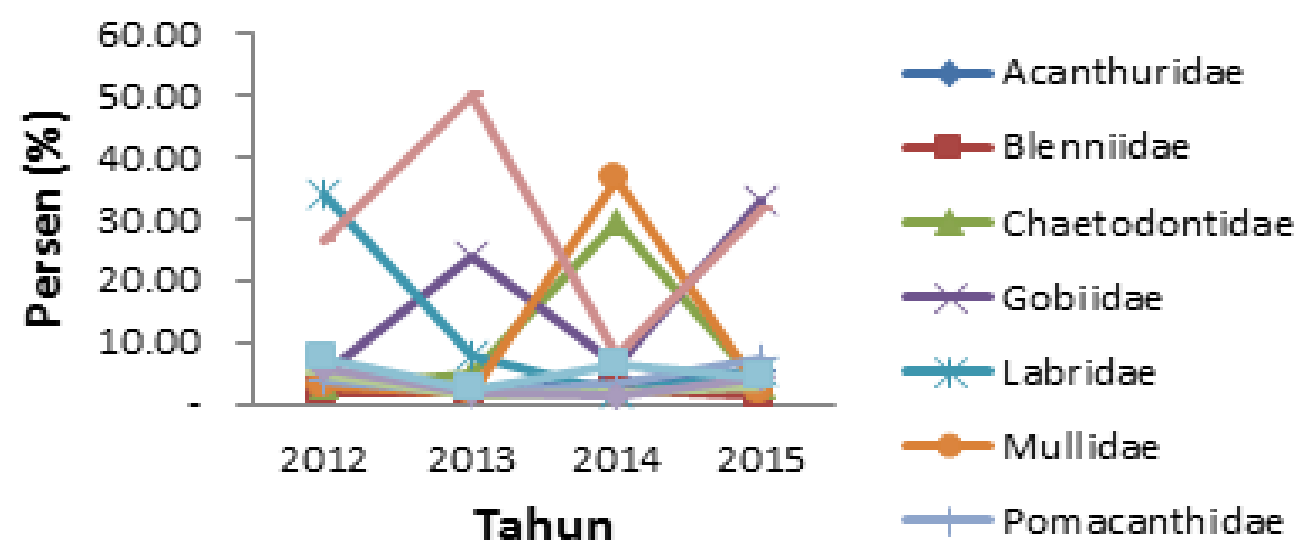

Gambar 3. Grafik data jenis hasil tangkapan ikan di Bangsring tahun 2012-2015

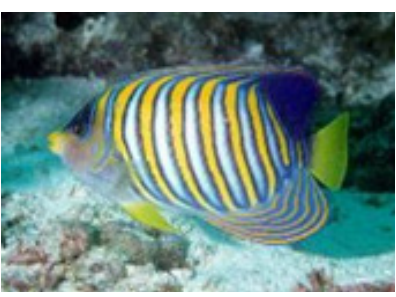

a

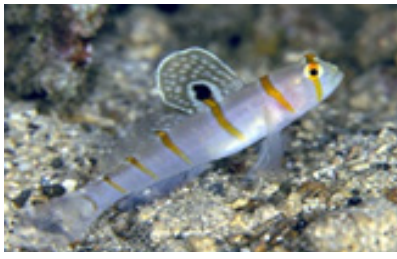

d

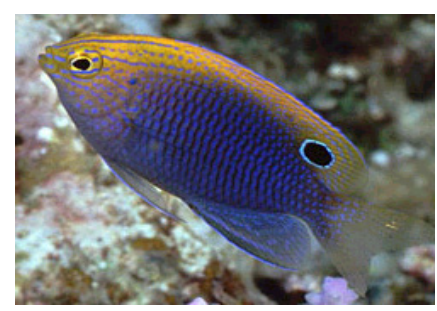

b

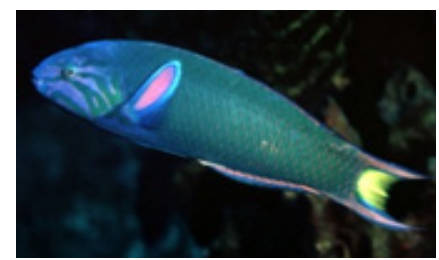

e
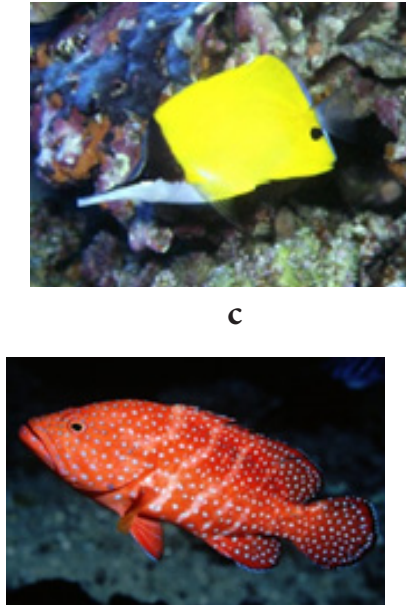

f

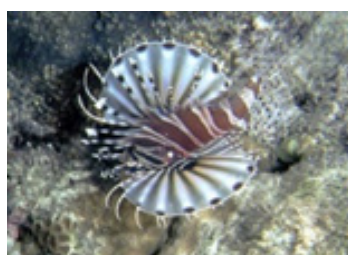

g

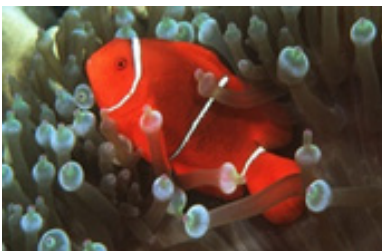

h

Gambar 4. Contoh jenis ikan hias hasil tangkapan nelayan Bangsring Banyuwangi : (a) angel fish (Pomacanthidae), (b) betok (Pomacentridae), (c) kepe-kepe (Chaetodotidae), (d) bunglon (Gobiidae), (e) keling (Labridae), (f) kerapu (Serranidae), (g) scorpion kembang

Jumlah hasil tangkapan dan pertambahan jenis ikan di perairan pantai Bangsring, Banyuwangi berangsur-angsur meningkat setiap tahunnya, hal tersebut berbanding lurus dengan lingkungan yang semakin baik. Bukan hanya hasil tangkapan saja. Akan tetapijumlah spesies juga semakin bertambah (Tabel 3). Terhitung pada tahun 2015 didapatkan hasil tangkapan 193 jenis ikan yang dapat dimanfaatkan oleh nelayan. Jenis ikan hias tangkapan nelayan yang paling banyak di fish apartment Bangsring rata-rata adalah ikan hias seperti angel fish
(Pomacanthidae), betok (Pomacentridae), kepe-kepe (Chaetodotidae), bunglon (Gobiidae), keling (Labridae), dan kerapu (Serranidae). Pemanfaatan fish apartment tentu sangat berpengaruh, terdapat perbedaan antara sebelum dan sesudah pemanfaatan fish apartment hal tersebut dapat dilihat pada Tabel 2.

Sebagian besar nelayan Bangsring Banyuwangi adalah nelayan yang menangkap ikan hias, sedangakan ikan konsumsi seperti kerapu, kakap dan baronang hanyalah sebagai ikan hasil 
tangkapan sampingan yang dapat di konsumsi sehari-hari. Nelayan tradisional mendapatkan hasil tangkapan ikan-ikan konsumsi di sekitar lokasi fish apartment. Ikan konsumsi yang tertarik pada terumbu karang buatan adalah famili Serranidae, Labridae, dan Siganidae. Sedangkan ikan hias taget hasil tangkapan seperti angel fish, bontana, trigger, kambigan, kepekepe, lintah, ikan tempel, bunglon, jabing, hogfish, betok, keling, scorpion, udangudangan, klonfish, cabing, kerapu, rainbow, buntal, dan lain-lain yang memiliki warna khas (Hutomo 1991).

Kesadaran nelayan akan penangkapan yang ramah lingkungan semakin tinggi dilihat dari berkurangnya penggunaan bahan penangkapan ikan yang berbahaya seperti potas. Berkat sosialisasi oleh pemerintah dan hasil tangkapan yang menurun nelayan Bangsring sadar akan penggunaan bahan kimia yang bersifat hanya sementara dalam pemanfaatannya, kesadaran nelayan akan tangkapan yang berkelanjutan tentu membuat nelayan Bangsring akan semakin mudah dalam mencari ikan. Penangkapan ikan oleh nelayan Bangsring beralih menggunakan jaring monofilamen yang digunakan untuk menghadang ikan saat di giring.

Kemudahan dalam mencari ikan dapat dilihat dari Tabel 2, perbedaan ratarata ikan hasil tangkapan yang naik hingga $110 \%$. Rata-rata hasil penangkapan ikan hias yang dilakukan oleh nelayan Bangsring naik menjadi 62 ekor/hari, yang sebelumnya hanya mendapatkan hasil tangkapan ikan 30 ekor/hari. Meningkatnya hasil tangkapan menandakan semakin baiknya perairan bangsring dilihat dari pertambahan jumlah dan jenis yang tertangkap. Rumpon dasar atau fish apartment merupakan suatu alat untuk memikat ikan agar berkumpul, beristirahat, berlindung, singgah, atau terkonsentrasi di sekitar rumpon, sehingga akan mempermudah nelayan dalam menentukan daerah penangkapan ikan (fishing ground). Pemasangan rumpon atau fish apartment menjadikan adanya kepastian daerah penangkapan ikan, maka waktu dan biaya operasi penangkapan bisa diprediksi secara akurat, sehingga usaha penangkapan ikan akan bisa menjadi lebih efektif dan efisien (Martasuganda 2008).

Mudahnya nelayan mencari ikan tentu berpengaruh dalam waktu mencari ikan. sebelum adanya fish apartment nelayan ikan hias Bangsring melakukan penangkapan ikan hingga pulau Bali, jarak antara perairan Banyuwangi dan Bali adalah 3 mil. Jarak yang jauh tentu berpengaruh pada waktu penangkapan dan biaya operasional yang tinggi. Waktu ratarata penangkapan ikan sebelum adanya fish apartment mencapai 7 jam, dengan adanya fish apartment waktu menjadi lebih efisien menjadi 4.5 jam dengan hasil tangkapan yang meningkat $110 \%$.

Adanya alat bantu fish apartment mampu merubah paradigma nelayan yang semula nelayan melaut untuk mencari ikan, kini berubah menjadi nelayan melaut untuk menangkap ikan. Berubahnya pradigma tersebut dikarenakan daerah penangkapan yang ditujunya sudah pasti, sehingga dapat menghemat waktu dan biaya oprasional (Budhiman 2011). Jarak penangkapan yang tidak jauh, waktu penangkapan yang singkat, hasil tangkapan yang banyak dan bervariasi menjadikan fish apartment adalah sebagai salah satu cara dalam pengembalian ekosistem yang rusak.

Tabel 2. Data perbandingan hasil wawancara di Bangsring, Banyuwangi

\begin{tabular}{|c|c|c|c|c|c|c|c|c|}
\hline \multirow{2}{*}{$\begin{array}{c}\text { Fish } \\
\text { Apartment }\end{array}$} & \multicolumn{2}{|c|}{ Alat tangkap } & \multicolumn{2}{|c|}{ Jenis ikan target } & \multirow{2}{*}{$\begin{array}{c}\text { Rata-rata } \\
\text { Hasil tangkapan }\end{array}$} & \multicolumn{2}{|c|}{ Jarak } & \multirow{2}{*}{$\frac{\text { Rata-rata }}{\text { waktu }}$} \\
\hline & Jenis & $\%$ & & & & & & \\
\hline \multirow[t]{3}{*}{ Sebelum } & Potas & 25 & Hias & Utama & 30 ekor & Jauh & $80 \%$ & \multirow{2}{*}{7 Jam } \\
\hline & Jaring & 60 & Konsumsi & Sampingan & $1 \mathrm{~kg}$ & Sedang & $20 \%$ & \\
\hline & Lain-lain & 15 & & & & Dekat & $0 \%$ & \multirow[b]{2}{*}{4.5 jam } \\
\hline Sesudah & $\begin{array}{l}\text { Potas } \\
\text { Jaring } \\
\text { Lain-lain }\end{array}$ & $\begin{array}{l}0 \\
90 \\
10\end{array}$ & $\begin{array}{l}\text { Hias } \\
\text { Konsumsi }\end{array}$ & $\begin{array}{l}\text { Utama } \\
\text { Konsumsi }\end{array}$ & $\begin{array}{l}63 \text { ekor } \\
2 \mathrm{~kg}\end{array}$ & $\begin{array}{l}\text { Jauh } \\
\text { Sedang } \\
\text { Dekat }\end{array}$ & $\begin{array}{l}0 \% \\
10 \% \\
90 \%\end{array}$ & \\
\hline
\end{tabular}


Tabel 3. Data jumlah jenis dan kelompok famili hasil tangkapan ikan di Bangsring, Banyuwangi 2012-2015

\begin{tabular}{|c|c|c|c|c|c|c|c|}
\hline \multicolumn{4}{|c|}{2012} & \multicolumn{4}{|c|}{2013} \\
\hline Famili & n spesies & n ekor & $\%$ & Famili & n spesies & n ekor & $\%$ \\
\hline Labridae & 32 & 2.235 & 33.90 & Pomacentridae & 16 & 2.076 & 50.27 \\
\hline Pomacentridae & 20 & 1.753 & 26.59 & Labridae & 24 & 996 & 24.12 \\
\hline Serranidae & 15 & 397 & 6.02 & Gobiidae & 10 & 191 & 4.62 \\
\hline Acanthuridae & 8 & 365 & 5.54 & Acanthuridae & 10 & 95 & 2.30 \\
\hline Pseudochromidae & 2 & 328 & 4.98 & Malacostraca & 5 & 86 & 2.08 \\
\hline Gobiidae & 11 & 322 & 4.88 & Serranidae & 8 & 83 & 2.01 \\
\hline Pomacanthidae & 11 & 256 & 3.88 & Microdesmidae & 4 & 76 & 1.84 \\
\hline Chaetodontidae & 14 & 177 & 2.69 & Pomacanthidae & 10 & 71 & 1.72 \\
\hline Mullidae & 3 & 169 & 2.56 & Chaetodontidae & 7 & 69 & 1.67 \\
\hline Blennidae & 1 & 116 & 1.76 & Pseudochromidae & 1 & 57 & 1.38 \\
\hline Microdesmidae & 4 & 86 & 1.30 & Zanclidae & 1 & 42 & 1.02 \\
\hline Malacostraca & 4 & 85 & 1.29 & Teraodontidae & 3 & 37 & 0.90 \\
\hline Haemulidae & 4 & 44 & 0.67 & Haemulidae & 4 & 35 & 0.85 \\
\hline Siganidae & 2 & 43 & 0.65 & Scorpaenidae & 3 & 31 & 0.75 \\
\hline Zanclidae & 2 & 43 & 0.65 & Siganidae & 2 & 29 & 0.70 \\
\hline Teraodontidae & 3 & 41 & 0.62 & Platacidae & 2 & 25 & 0.61 \\
\hline Psettodidae & 1 & 17 & 0.26 & Antennaridae & 1 & 15 & 0.36 \\
\hline Scorpaenidae & 1 & 16 & 0.24 & Psettodidae & 1 & 15 & 0.36 \\
\hline Syngnathidae & 4 & 13 & 0.20 & Tripterygiidae & 1 & 15 & 0.36 \\
\hline Muraenidae & 1 & 11 & 0.17 & Discodorididae & 2 & 14 & 0.34 \\
\hline Ostraciidae & 2 & 11 & 0.17 & Balistidae & 2 & 12 & 0.29 \\
\hline Scaridae & 1 & 9 & 0.14 & Muraenidae & 3 & 11 & 0.27 \\
\hline Balistidae & 4 & 7 & 0.11 & Stichodactylidae & 3 & 10 & 0.22 \\
\hline Antennaridae & 1 & 6 & 0.09 & Scaridae & 1 & 9 & 0.19 \\
\hline Holocentridae & 1 & 6 & 0.09 & Syngnathidae & 2 & 9 & 0.19 \\
\hline Discodorididae & 1 & 5 & 0.08 & Caesionidae & 2 & 7 & 0.12 \\
\hline Platacidae & 2 & 5 & 0.08 & Ostraciidae & 3 & 6 & 0.12 \\
\hline Tripterygiidae & 1 & 5 & 0.08 & Mullidae & 2 & 4 & 0.10 \\
\hline Lutjanidae & 1 & 4 & 0.06 & Lutjanidae & 1 & 2 & 0.02 \\
\hline Echeneidae & 1 & 4 & 0.05 & Sphyraenidae & 1 & 2 & 0.02 \\
\hline Malacanthidae & 1 & 3 & 0.05 & & 164 & 4.130 & 100.00 \\
\hline Monacanthidae & 1 & 3 & 0.05 & & & & \\
\hline Sphyraenidae & 1 & 3 & 0.03 & & & & \\
\hline Ammotheidae & 1 & 2 & 0.02 & & & & \\
\hline Nemipteridae & 1 & 1 & 0.02 & & & & \\
\hline \multirow[t]{2}{*}{ Stichodactylidae } & 1 & 1 & 0.02 & & & & \\
\hline & 164 & 6.592 & 100.00 & & & & \\
\hline
\end{tabular}




\begin{tabular}{|c|c|c|c|c|c|c|c|}
\hline \multicolumn{4}{|c|}{2014} & \multicolumn{4}{|c|}{2015} \\
\hline Famili & n spesies & n ekor & $\%$ & Famili & n spesies & n ekor & $\%$ \\
\hline Pomacentridae & 20 & 3.282 & 36.67 & Labridae & 33 & 4.220 & 32.86 \\
\hline Labridae & 35 & 2.642 & 29.52 & Pomacentridae & 21 & 4.055 & 31.57 \\
\hline Serranidae & 12 & 696 & 7,78 & Pomacanthidae & 16 & 927 & 7.22 \\
\hline Pomacanthidae & 11 & 570 & 6.37 & Acanthuridae & 12 & 685 & 5.33 \\
\hline Pseudochromidae & 1 & 302 & 3.37 & Malacostraca & 7 & 566 & 4.41 \\
\hline Acanthuridae & 13 & 281 & 3.14 & Serranidae & 6 & 526 & 4.10 \\
\hline Chaetodontidae & 6 & 196 & 2.19 & Gobiidae & 11 & 380 & 2.96 \\
\hline Malacostraca & 4 & 163 & 1.82 & Pseudochromidae & 2 & 328 & 2.55 \\
\hline Teraodontidae & 1 & 145 & 1.62 & Mullidae & 3 & 259 & 2.02 \\
\hline Zanclidae & 7 & 124 & 1.39 & Chaetodontidae & 17 & 196 & 1.53 \\
\hline Gobiidae & 1 & 109 & 1.22 & Microdesmidae & 8 & 145 & 1.13 \\
\hline Sphyraenidae & 3 & 77 & 0.86 & Blennidae & 1 & 136 & 1.06 \\
\hline Microdesmidae & 1 & 59 & 0.66 & Teraodontidae & 3 & 121 & 0.94 \\
\hline Mullidae & 5 & 55 & 0.61 & Zanclidae & 2 & 77 & 0.60 \\
\hline Scorpaenidae & 2 & 51 & 0.57 & Haemulidae & 7 & 49 & 0.38 \\
\hline Siganidae & 2 & 50 & 0.56 & Siganidae & 2 & 43 & 0.33 \\
\hline Discodorididae & 3 & 33 & 0.37 & Muraenidae & 2 & 22 & 0.17 \\
\hline Haemulidae & 2 & 24 & 0.27 & Psettodidae & 1 & 17 & 0.13 \\
\hline Caesionidae & 3 & 15 & 0.17 & Syngnathidae & 4 & 12 & 0.09 \\
\hline Balistidae & 3 & 14 & 0.16 & Ostraciidae & 2 & 10 & 0.08 \\
\hline Syngnathidae & 1 & 12 & 0.13 & Scaridae & 2 & 10 & 0.08 \\
\hline Ostraciidae & 2 & 9 & 0.10 & Stichodactylidae & 2 & 9 & 0.07 \\
\hline Stichodactylidae & 5 & 9 & 0.10 & Balistidae & 4 & 8 & 0.05 \\
\hline Scaridae & 1 & 6 & 0.07 & Platacidae & 2 & 7 & 0.05 \\
\hline Platacidae & 2 & 6 & 0.06 & Antennaridae & 1 & 6 & 0.05 \\
\hline Holocentridae & 1 & 5 & 0.06 & Discodorididae & 1 & 5 & 0.04 \\
\hline Blennidae & 1 & 4 & 0.04 & Holocentridae & 1 & 5 & 0.04 \\
\hline Lutjanidae & 1 & 4 & 0.03 & Tripterygiidae & 1 & 5 & 0.04 \\
\hline Malacanthidae & 1 & 2 & 0.02 & Lutjanidae & 1 & 4 & 0.02 \\
\hline Muraenidae & 1 & 2 & 0.02 & Monacanthidae & 1 & 3 & 0.02 \\
\hline Echeneidae & 1 & 1 & 0.01 & Echeneidae & 1 & 2 & 0.02 \\
\hline \multirow{5}{*}{ Monacanthidae } & 1 & 1 & 0.01 & Malacanthidae & 1 & 2 & 0.02 \\
\hline & 156 & 8.949 & 100.00 & Sphyraenidae & 1 & 2 & 0.02 \\
\hline & & & & Ammotheidae & 1 & 1 & 0.01 \\
\hline & & & & Nemipteridae & 1 & 1 & 0.01 \\
\hline & & & & & 191 & 12.844 & 100.00 \\
\hline
\end{tabular}




\section{KESIMPULAN DAN SARAN}

\section{KESIMPULAN}

Penanaman fish apartment pada perairan Bangsring, Banyuwangi dapat meningkatkan jenis dan hasil tangkapan. Hasil analisis keberadaan fish apartment berhasil memperbaiki populasi dan lingkungan habitat ikan dan mempengaruhi efisensi penangkapan baik dari jarak, waktu dan hasil tangkapan.

\section{SARAN}

Pengkayaan sumberdaya ikan dengan fish apartment sebaiknya memiliki wilayah dan peraturan konservasi yang jelas, agar perbaikan lingkungan di perairan Bangsring dapat berjalan dengan baik.

\section{DAFTAR PUSTAKA}

Anwar JAJ, Whitten SJD, Hisyam N. 1984. Ekologi ekosistem sumatera. Yogyakarta: Gadjah Mada University Press.

Bambang N, Widodo, Suryadi A, Wassahua Z. 2011. Apartemen ikan (Fish Apartment) sebagai pilar pelestarian sumberdaya ikan. Balai Besar Pengembangan Penangkapan Ikan, Direktorat Jendral Perikanan Tangkap, Kementrian Kelautan dan Perikanan.

Budhiman AA. 2011. Panduan pelaksanaan pengembangan rumah ikan dalam rangka pemulihan sumberdaya ikan. Direktorat Sumberdaya Ikan dan Balai Besar Pengembangan Penangkapan Ikan Semarang, Direktorat Jendral Perikanan Tangkap.

Budhiman AA, Christijanto H, Wulandari W, Jimmi, Budiarto A, Wahyudi CR, Andira
A, Sutriyono, Hudaya Y, Malik R, Dwi M. 2013. Petunjuk teknis rumah ikan dalam rangka pemulihan sumberdaya ikan (Cetakan Revisi Ke-2). Direktorat Sumberdaya Ikan dan Balai Besar Pengembangan Sumberdaya Ikan Semarang, Direktorat Jendral Perikanan Tangkap.

Connel R. 1987. Ecological studies in tropical fish communities. Cambridge University Press. Cambridge.

Greenberg. 1989. Standard methods for the examination of water and wastewater for 4th Edition. American Publich Health Assosiation. Washington.

Hutomo M. 1991. Teknologi terumbu buatan: suatu upaya untuk meningkatkan sumberdaya hayati laut. Jurnal Oseana, Volume XVI, 1: 23 -33.

Mahyudin B. 2012. Kebutuhan teknologi untuk penangkapan ikan. Seminar nasional kelautan VIII Universitas Hang Tuah. Surabaya.

Mallawa AH, Sudirman H. 2004. Teknik penangkapan ikan. Rineka Cipta, Jakarta.

Martasuganda S. 2008. Rumpon-rumah pondok ikan (Fish Aggregation Device). Departemen Pemanfaatan Sumberdaya Perikanan dan Pusat Kajian Sumberdaya pesisir dan Lautan. Institut Pertanian Bogor.

Mulatsih S. 2004. Efek keberadaan terumbu karang buatan terhadap komunitas sumberdaya hayati di perairan Karang Jeruk Tegal. [Tesis]. Semarang: Program Pascasarjana Universitas Diponogoro.

Sutarto. 2000. Pengenalan tentang rumpon dan terumbu karang buatan. Balai Besar Pengembangan Penangkapan Ikan Semarang, Direktorat Jendral Perikanan Tangkap. 